\title{
Addition of Coconut Water and Banana Extract on MS Media to Stimulate PLB (Protocorm Like Bodies) Regeneration of Dendrobiumgatton sunray
}

\author{
R. Herawati ${ }^{1 *}$, D. W. Ganefianti ${ }^{1}$, A. Romeida ${ }^{1}$, Marlin $^{1}$, Rustikawati ${ }^{1}$, Habibi $^{2}$ \\ ${ }^{1}$ Agroecotechnology at Crop Production Dept, Fac. of Agriculture, Univ. of Bengkulu, Bengkulu 38122, Indonesia \\ ${ }^{2}$ Student of Agroecotechnology Study Programme, Fac. of Agriculture, Univ. of Bengkulu, Bengkulu 38122, Indonesia \\ *Corresponding author.Email: reny.herawati@unib.ac.id
}

\begin{abstract}
Organic material is widely used for propagation of orchids, namely coconut water, extracts of tomatoes, bananas, bean sprouts and potatoes which can be added to certain media as a provider of nutrients, amino acid minerals, and growth regulators. This study aims to determine the effect of the concentration of organic matter in coconut water and banana extract on MS media on the regeneration of PLB (protocorn like bodies) Dendrobiumgatton sunray. The study was conducted at the Biotechnology Laboratory, Faculty of Agriculture, Bengkulu University, from September to December 2019. This study used a Complete Randomized Block Design (RCBD) with two factors. The first factor was the concentration of coconut water with 3 levels namely: $\mathrm{A} 0=0$ (Control), $\mathrm{A} 1=75 \mathrm{ml} . \mathrm{L}^{-1}, \mathrm{~A} 2=150 \mathrm{ml} \cdot \mathrm{L}^{-1}$, and the second factor was the concentration of banana extract with 5 levels namely: $\mathrm{B} 0=0$ (Control), $\mathrm{B} 1=75 \mathrm{~g} \cdot \mathrm{L}^{-1}, \mathrm{~B} 2=150 \mathrm{~g} \cdot \mathrm{L}^{-1}$. The results showed that coconut water did not affect all variables, however the banana extract had a significant effect on all variables except for the number of shoots. There was an interaction between the two treatments, namely the variable plantlet weight. Orthogonal polynomial analysis showed that there was an interaction between the two treatments, where coconut water and banana extract had a good response on the plantlet growth when given together as much as $75 \mathrm{ml} . \mathrm{L}^{-1}$ (A1) and 75 g.L.-1 (B1). The concentration of both treatment was lower than it was given individually.
\end{abstract}

\section{Keywords: coconut water, bananas extracts, Dendrobiumgatton sunray, MS media}

\section{INTRODUCTION}

Dendrobium is a type of orchid that is favoured by orchid enthusiasts because it has a variety of forms, shapes, and even sizes, it is even easy to maintain and cultivate, and the price is relatively affordable. In addition, Dendrobium also has other features such as the freshness of long-lasting flowers, flexible flower stalks [1] so that it is widely used as an ornamental plant in the form of cut flowers that can decorate spaces with good quality [2]. According to Suryana [3] orchids had entered the international market for export to destination countries, including Japan, the Netherlands, Korea and Singapore. The Indonesian Statistics Agency [4] notes that the value of orchid production in Indonesia from 2016 to 2017 had increased between $19,978,078$ stalks to $20,045,577$ stalks with an average export value of 120,560 US dollars. Financially the orchid farming gives a profit, where in one growing season it provides a profitability (ROI) of $70 \%$ of the funds invested. Value added along the marketing chain show a reasonable profit for the business (farmers and traders) as well, so that this commodity business has good prospects [5].
In general, orchids are only able to reproduce in nature at less than $1 \%$, this is because orchid seeds are very small and do not have an endosperm so that orchids are symbiotic with mycorrhizae in nature. The role of mycorrhizae as a supplier of carbon sources for orchid seed germination in general has been replaced by tissue culture media. Optimization of tissue culture techniques continues to be carried out in an effort to accelerate the propagation of orchids, this technique only requires a small part of the plant to obtain the same plantlets as the parent [6].

The orchid seeds will grow into protocorms in the germination medium. Protocorm can form a secondary protocorm (protocorm like body/PLB). In vitro regeneration of PLB Dendrobium for shoot multiplication is generally carried out on media enriched with growth regulators and vitamins. One of the keys to success is the use of media types and growth regulators at the right concentration. The composition of the media used greatly determines the growth rate of protocorms and plantlets and is useful for increasing the quality and quantity of seedlings [7]. The composition of the media needed in tissue culture must contain nutrients that are useful for plants, namely consisting of carbohydrates, sugars and vitamins. Tissue culture media usually uses artificial 
media compositions, namely Murashige and Skoog and Knudson C media, either half or full concentration. The composition of the media is a determining factor in the success of in vitro orchid culture. Growth and reproduction rates of many species of orchids enhanced by adding some organic supplements such as coconut water $(\mathrm{CW})$ or potato extract to culture medium [8-9]. Growth regulators are usually added to the medium to promote growth of explants. The growth regulators commonly used are auxins and cytokinins. The composition of the media can also be obtained from organic materials which already have natural nutrients and hormones in the form of auxins and cytokinins known as phytohormones. Complex organic materials can be used as additives that can encourage the development and growth of propagation explants in tissue culture [10-9]. The addition of organic materials such as extracts bananas, potato pulp and vegetable substances others have content high carbohydrate can increase growth and differentiation of cells in plants [11].

Organic materials that are widely used for orchid propagation are coconut water, tomato extracts, bananas, bean sprouts and potatoes which can be added with certain media as a provider of nutrients, amino acids, and growth regulators for orchid growth. Coconut water has been widely used as an additive in tissue culture media. The content of coconut water is in the form of active ingredients that are useful for the growth of plantlets which are rich in vitamins, sugars, amino acids and phytohormones [12-14]. Nurfadilah et al. [15] research showed that the combination of Ambon banana and BAP on concentration $10^{-6} \mathrm{M}$ BAP and $2.5 \%$ banana extract Ambon produces the best growth on time of emergence of shoots, number of shoots and number of leaves. This research was conducted to modify the MS media with added coconut water and banana extract to stimulate the regeneration of PLB Dendrobiumgatton sunray.

\section{MATERIAL AND METHODS}

The research was conducted at the Laboratory of Agricultural Cultivation, Division of Tissue Culture and Biotechnology, Faculty of Agriculture, Bengkulu University. This research was conducted from September to December 2019. The materials used were PLB which had formed 2-3 mm buds as plantlets, banana extract, coconut water, Murashige \& Skoog (MS) media, sugar, $70 \%$ alcohol, alcohol. $96 \%$, and aquadest.

The design method used was a factorial completely randomized design (CRD) with 2 factors, namely: the first factor was coconut water with 3 levels, namely: $\mathrm{A} 0=0$ (Control), A1 $=75 \mathrm{ml} . \mathrm{L}^{-1}, \mathrm{~A} 2=150 \mathrm{ml} \cdot \mathrm{L}^{-1}$. The second factor was banana extract with 3 levels, namely: $\mathrm{B} 0=0$ (Control), B1 = 75 g.L $\mathrm{L}^{-1}, \mathrm{~B} 2=150$ g.L $\mathrm{L}^{-1}$. Each treatment combination was repeated 5 times. One experimental unit consisted of one culture bottle planted with 3 PLBs.

A total of $1 / 2$ MS medium was added to treatment, added sugar as much as 30 g.L. $\mathrm{L}^{-1}$, gelatin as much as 7 g.L1 , then the media $\mathrm{pH}$ was measured 5.8. The media was cooked until the gelatin was dissolved and well blended, then immediately poured into a sterile bottle with a volume of $20 \mathrm{ml}$ bottle-1, then the media was sterilized by autoclave at a temperature of $121^{\circ} \mathrm{C}, 15$ psi pressure for 15 minutes. The explants used in the study were not uniformed into other media and were directly planted in the experimental media. The explants were removed from the bottle and selected for uniform growth. The selected explants consisted of 2 explants per bottle which were sterile, then the bottles were covered with plastic and tied with a rubber band and given a tight wrap. The culture bottles were maintained in the culture room at a temperature of $19-20^{\circ} \mathrm{C}$ with $\pm 1,000$ lux irradiation for 12-16 hours / day.

Observations were made one week after planting (WAF) to 15 weeks (WAF). Every day the plants were checked for contaminants and browning, while the last week observations were made on the variables of the number of leaves, number of roots, length of leaves, length of shoots, number of shoots, and weight of plantlets.

Data were analyzed using analysis of variance at the 5\% level, and further tests with LSD at the 5\% level. The orthogonal polynomial test was used to determine the treatment and interaction patterns [16].

\section{RESULTS AND DISCUSSION}

Variance analysis showed that coconut water had no effect on all observed variables, however banana extract had a significant effect on all observed variables except for the number of shoots (Table 1). There was an interaction between the two treatments, namely the plantlet weight. The orthogonal polynomial analysis showed that the pattern of coconut water on the leaf length was very significant in a quadratic curve, while the banana extract pattern was very significant quadratic on the variable shoot length, leaf length, root length, number of leaves, number of roots, and plantlet weight, except that the number of shoots tended to be linear. (Table 1). Even though there was only an interaction on plantlet weight, the interaction pattern between the addition of coconut water and banana extract tended to be quadratic in the variables of shoot length, number of leaves, number of shoots, number of leaves, and plantlet weight (Table 1).

\subsection{The effect of coconut water to MS media on the regeneration of PLB (Protocorm Like Bodies) Dendrobium sp.}

The effect of coconut water on PLB (Protocorm Like Bodies) regeneration was not significantly different in all observed variables. However, the pattern of coconut water tends to be quadratic in leaf length (Figure 1) with the regression equation $\mathrm{Y}=-0.005 \mathrm{X}^{2}+0.008 \mathrm{X}+3.667$ and the value of $R^{2}=1$. The addition of coconut water up to $150 \mathrm{ml}$ to the media had not shown a significant effect, because the curve tends to increase and has not shown an optimal point, however, it was estimated that the optimal point was achieved in the addition of $150-200 \mathrm{ml} / \mathrm{l}$ coconut water. 
Table 1Analysis of variance and orthogonal polynomials on the addition of coconut water and banana extract to MS media to stimulate the regeneration of PLB (Protocorm Like Bodies) Dendrobiumgatton sunray

\begin{tabular}{|c|c|c|c|c|c|c|c|}
\hline \multirow[b]{2}{*}{ Source of variance } & \multicolumn{7}{|c|}{ F value } \\
\hline & $\begin{array}{l}\text { Shoot } \\
\text { length }\end{array}$ & $\begin{array}{c}\text { Leaf } \\
\text { length }\end{array}$ & $\begin{array}{l}\text { Root } \\
\text { length }\end{array}$ & $\begin{array}{l}\text { Number } \\
\text { of shoot }\end{array}$ & $\begin{array}{c}\text { Number } \\
\text { of leaf }\end{array}$ & $\begin{array}{c}\text { Number } \\
\text { of root }\end{array}$ & $\begin{array}{l}\text { Weight } \\
\text { plantlet }\end{array}$ \\
\hline Coconut water & 0.07 & 0.48 & 0.22 & 0.11 & 0.27 & 0.17 & 0.14 \\
\hline Banana extract & $1.56^{*}$ & $1.41 *$ & $0.94 *$ & 0.39 & $0.94 *$ & $1.71 *$ & $1.48 *$ \\
\hline C. water x B. extact & 0.59 & 0.63 & 0.19 & 0.48 & 0.46 & 0.08 & $1.10^{*}$ \\
\hline C. water linier & 0.07 & 0.46 & 0.09 & 0.10 & 0.10 & 0.16 & 0.29 \\
\hline C. water kuadratic & 0.06 & $0.50^{*}$ & 0.34 & 0.12 & 0.44 & 0.19 & 0.01 \\
\hline B. extract linier & $1.49 *$ & 0.15 & 0.12 & $0.76^{*}$ & $1.06^{*}$ & 0.09 & 0.26 \\
\hline B. extract kuadratic & $1.63 *$ & $2.67 *$ & $1.77 *$ & 0.01 & $0.82 *$ & $3.33 *$ & $2.69 *$ \\
\hline C. water linier x B. extract linier & $0.93 *$ & $0.59 *$ & 0.07 & 0.13 & 0.03 & 0.14 & $1.40 *$ \\
\hline C. water linier x B. extract kuadratic & 0.03 & $0.56^{*}$ & $0.53 *$ & 0.14 & 0.01 & 0.04 & $1.43^{*}$ \\
\hline C. water kuadratic $\mathrm{x}$ B. extract linier & $1.33 *$ & $0.98 *$ & 0.02 & $1.06^{*}$ & $1.39 *$ & 0.06 & $1.43 *$ \\
\hline
\end{tabular}

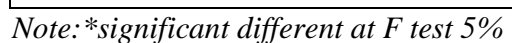
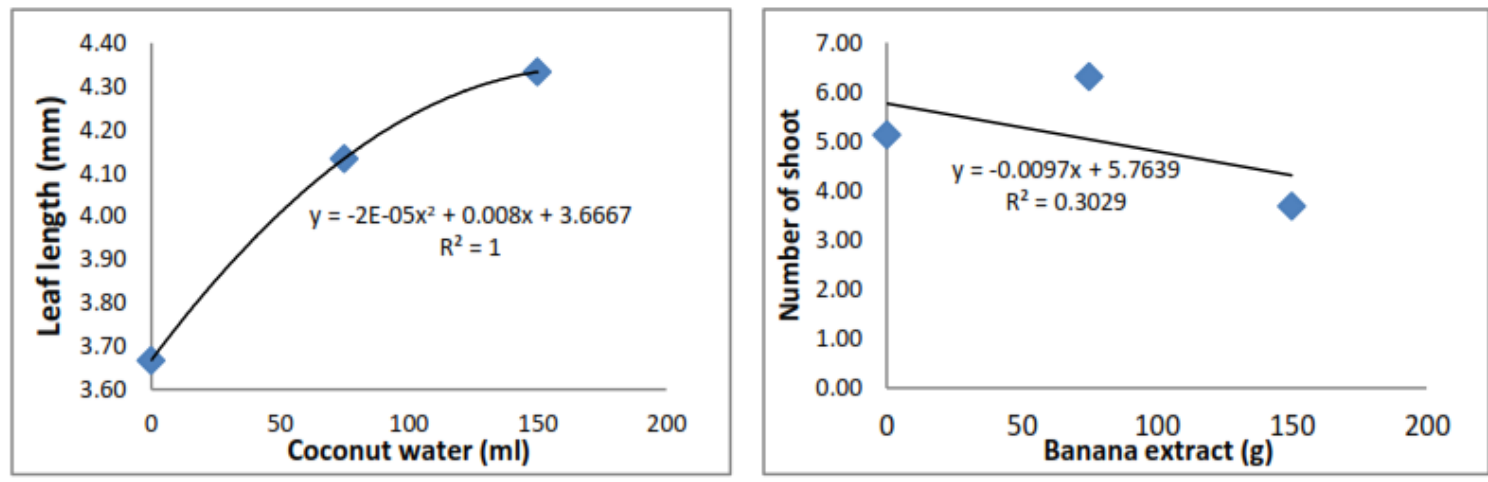

Figure 1 Respon of coconut water on the leaf length

Figure 2 Respon of Banana extract on the number of shoot
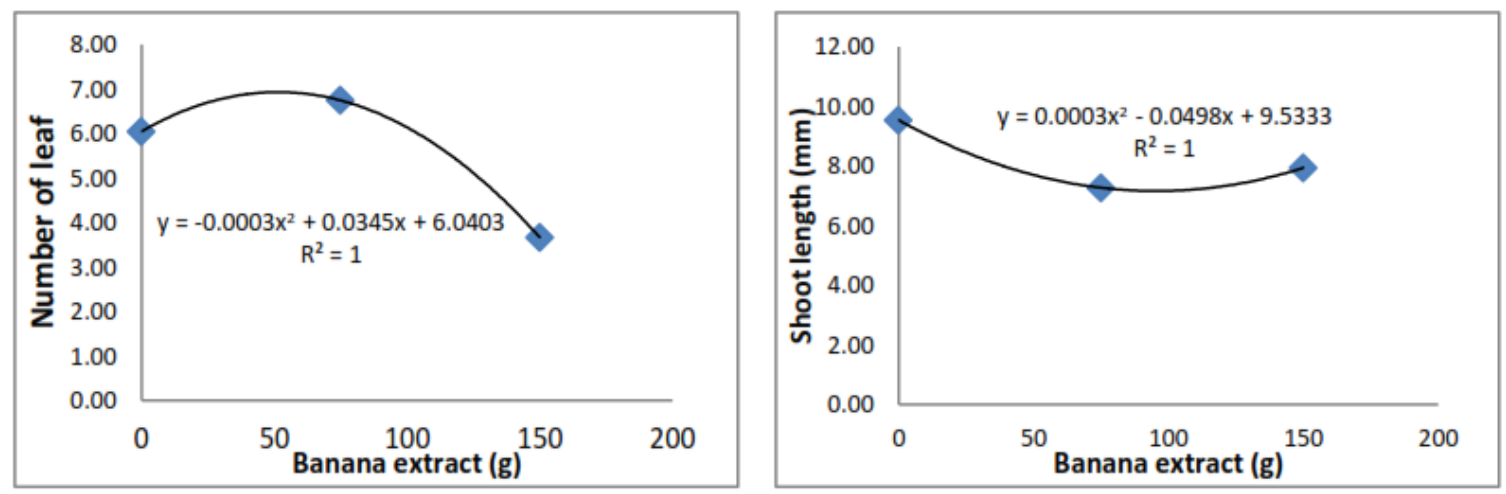

Figure 3 Respon of Banana extract on the number of leaf

Figure 4 Respon of Banana extract on the shoot length 


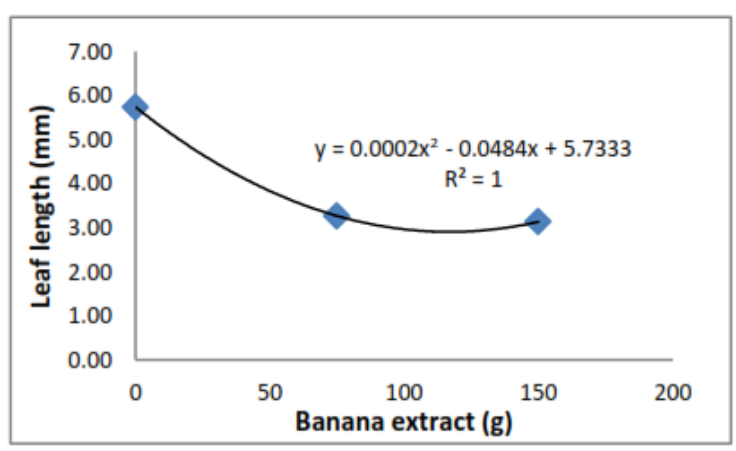

Figure 5 Respon of Banana extract on the leaf length

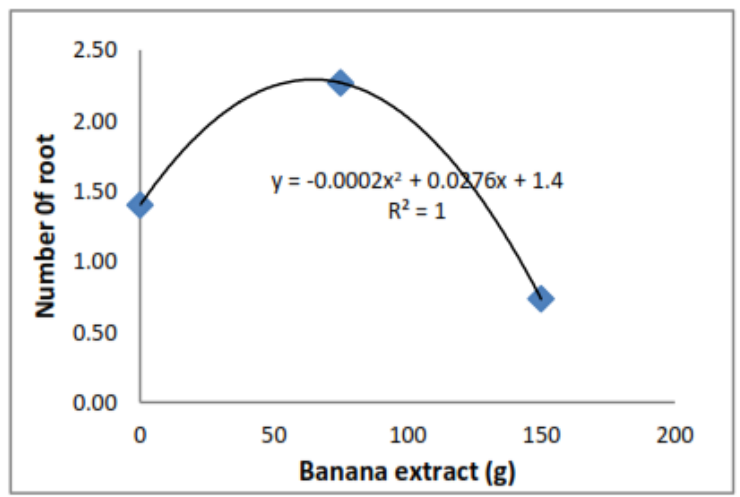

Figure 7 Respon of Banana extract on the number of root

Similar research by Pranata et al. [17] showed that the addition of $22.5 \%$ coconut water gave the best shoot length, then added with the addition of $15 \%$ coconut water. In addition, refers to Erfa et al. [18] in their research reported that the addition of coconut water up to $150 \mathrm{ml}$ in the Phalaenopsis orchid growing medium resulted in better seedling height growth. Kristina et al. [19] stated that coconut water contains IAA (auxin) and cytokinins which were very good for stimulating plant growth and shoot growth. Coconut water has been used in tissue culture methods because of its growth regulating properties and cytokinin activity that supports cell division and promoting rapid growth [20]. The higher coconut water concentrations promoted better growth and shoot propagation in some orchid species, and the coconut water effect depending on the species and the explants [8-9].

\subsection{The effect of banana extract on MS media on the regeneration of PLB Dendrobiumgatton sunray}

The effect of banana extract on PLB regeneration is presented in Table 2. The results showed that although it was significantly different in the $\mathrm{F}$ test, the average between treatments did not show a significant difference. The addition of banana extract $75 \mathrm{~g} \mathrm{~L}^{-1}$ had the highest root length with an average of $3.2 \mathrm{~mm}$, the number of leaves was 6.74, and the number of roots was 2.27 (Table

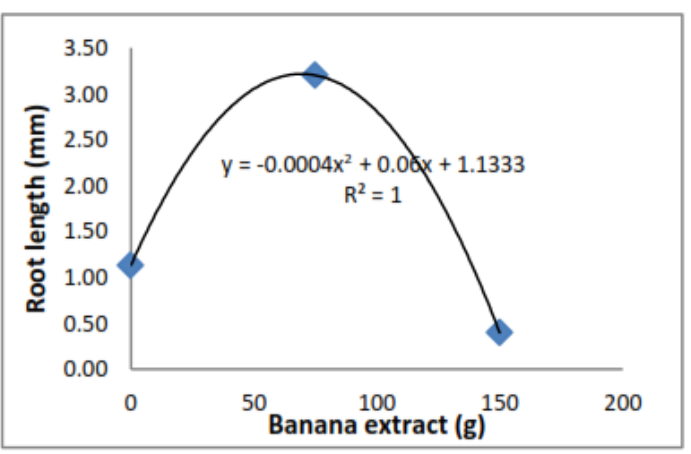

Figure 6 Respon of Banana extract on the root length

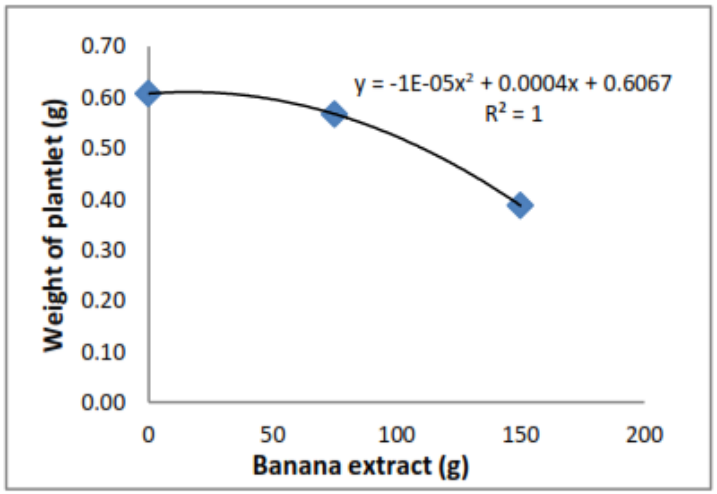

Figure 8 Respon of Banana extract on the weight of plantlet

2). Giving banana extract to the media because it was a source of carbohydrates and contains several minerals and various vitamins such as vitamin $\mathrm{C}$ and especially thiamine. Refer to Kasutjianingati and Irawan's [21] research showed that Ambon banana extract has a good effect on the root length of Dendrobium.

The orthogonal polynomial analysis showed that the banana extract response was very significant with a quadratic pattern on the variable shoot length, leaf length, root length, number of leaves, number of roots, and plantlet weight (Table 1), except that the number of shoots tended to be linear (Figure 2). This indicated that the optimum point has not been reached for the variable number of shoots.

The addition of banana extract forms a quadratic pattern on the number of leaves with the equation $\mathrm{Y}=$ $0.0003 \mathrm{X} 2+0.035+6.04(\mathrm{R} 2=1)$, and reaches an optimum point in the addition of $50-100 \mathrm{mg}$ of banana extract (Figure 3). The same pattern was also found in root length (Figure 6), number of roots (Figure 7), and plantlet weight (Figure 8). Different patterns were found in shoot length (Figure 4) and leaf length (Figure 5), where it reached the lowest point at the addition of 50-100 $\mathrm{g}$ of banana extract. Refer to Hendaryono [22] in his study on banana extract $300 \mathrm{~g} / \mathrm{l}$ resulted in a lower number of leaves.

The highest average shoot length, leaf length, and plantlet weight without banana extract treatment (B0) 
were $9.53,5.73$, and 0.61 respectively, while in treatment (B1) the root length, number of leaves and number of roots, respectively amounting to $3.20,6.74$, and 2.27 (Table 2).Banana extract apart functions as a coenzyme for several reactions in metabolism and also plays a role in the metabolism of energy derived from carbohydrates. Giving Ambon banana fruit extract in the sub-culture plantlet can stimulated the growth of Dendrobium. Banana fruit also contains natural hormones auxins and gibberellins which can stimulate growth plantlets $[21 ; 23]$

\subsection{The interaction effect of coconut water and banana extract on MS media on the regeneration of $P L B$ Dendrobiumgatton sunray}

Based on orthogonal polynomial analysis, it showed that although there was only an interaction on plantlet weight, the interaction pattern between coconut water and banana extract tends to be quadratic in the variables shoot length, number of leaves, number of shoots, number of leaves, and plantlet weight (Table 1). The interaction effect between coconut water at various levels of banana extract was found in the variables of leaf length, root length, and plantlet weight (Figure 9-11). The effect of the interaction between coconut water at various levels of banana extract was found in the variables of leaf length, root length, and plantlet weight. Meanwhile, the effect of the interaction between banana extracts at various levels of coconut water was found in the variable shoot length, number of shoots, leaf length, number of leaves, and plantlet weight (Figure 12-16). Coconut water treatment gives a good response when given together with banana extract as much as $75 \mathrm{mg}$ (B1) on the variable leaf length (Figure 9), root length (Figure 10), and plantlet weight (Figure 11), where coconut water reaches its optimum. at concentrations between $50-100 \mathrm{ml} . \mathrm{L}^{-1}$.

Table 2 Effect of banana extract on the Shoot length, Leaf length, Root length, Number of leaf, Number of root, and Weight plantlet

\begin{tabular}{|c|c|c|c|c|c|c|}
\hline \multirow{2}{*}{ Treatment } & \multicolumn{7}{|c|}{ Means of treatment } \\
\cline { 2 - 7 } & Shoot length & $\begin{array}{c}\text { Leaf } \\
\text { length }\end{array}$ & $\begin{array}{c}\text { Root } \\
\text { length }\end{array}$ & $\begin{array}{c}\text { Number of } \\
\text { leaf }\end{array}$ & $\begin{array}{c}\text { Number of } \\
\text { root }\end{array}$ & $\begin{array}{c}\text { Weight } \\
\text { plantlet }\end{array}$ \\
\hline B0 & $9.53 \mathrm{a}$ & $5.73 \mathrm{a}$ & $1.13 \mathrm{a}$ & $6.04 \mathrm{a}$ & $1.40 \mathrm{a}$ & $0.61 \mathrm{a}$ \\
\hline B1 & $7.27 \mathrm{a}$ & $3.27 \mathrm{a}$ & $3.20 \mathrm{~b}$ & $6.74 \mathrm{a}$ & $2.27 \mathrm{a}$ & $0.57 \mathrm{a}$ \\
\hline B2 & $7.93 \mathrm{a}$ & $3.13 \mathrm{a}$ & $0.40 \mathrm{a}$ & $3.66 \mathrm{~b}$ & $0.73 \mathrm{a}$ & $0.39 \mathrm{a}$ \\
\hline
\end{tabular}

Note: LSD 5\%

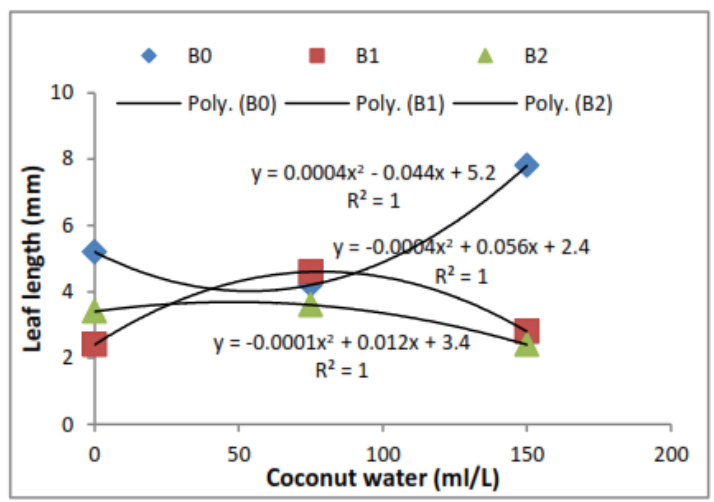

Figure 9 Response of leaf length on the coconut water at the various levels of banana extract

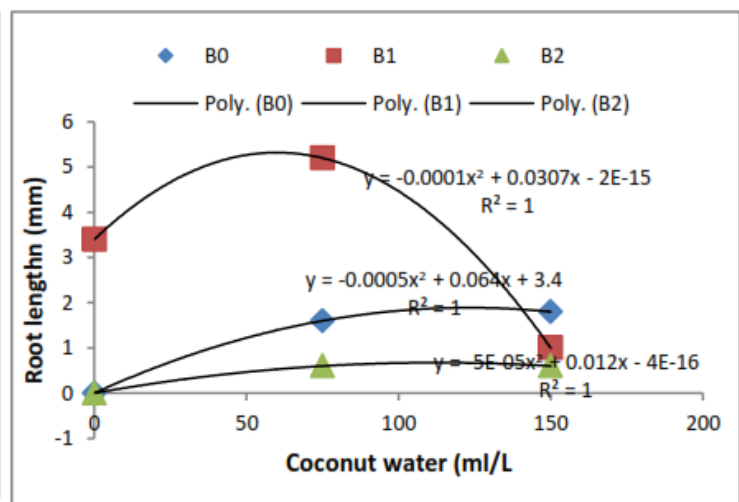

Figure 10 Response of root length on the coconut water at the various levels of banana extract 


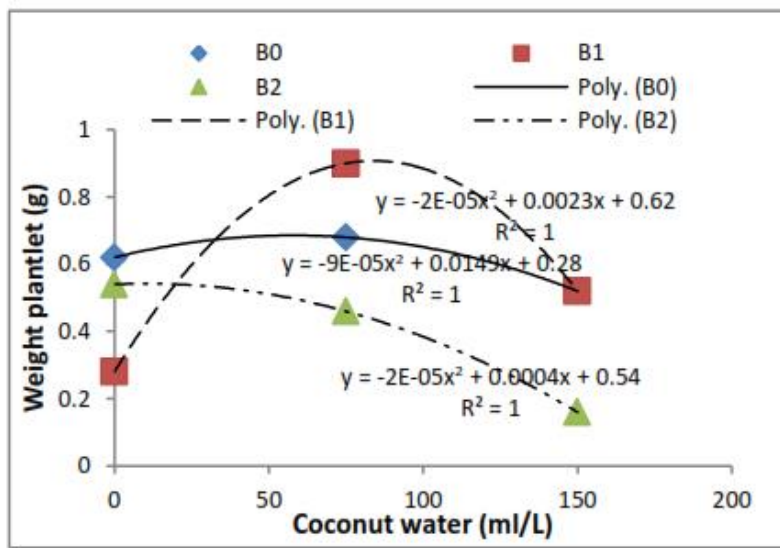

Figure 11. Response of weight plantlet on the coconut water at the various levels of banana extract

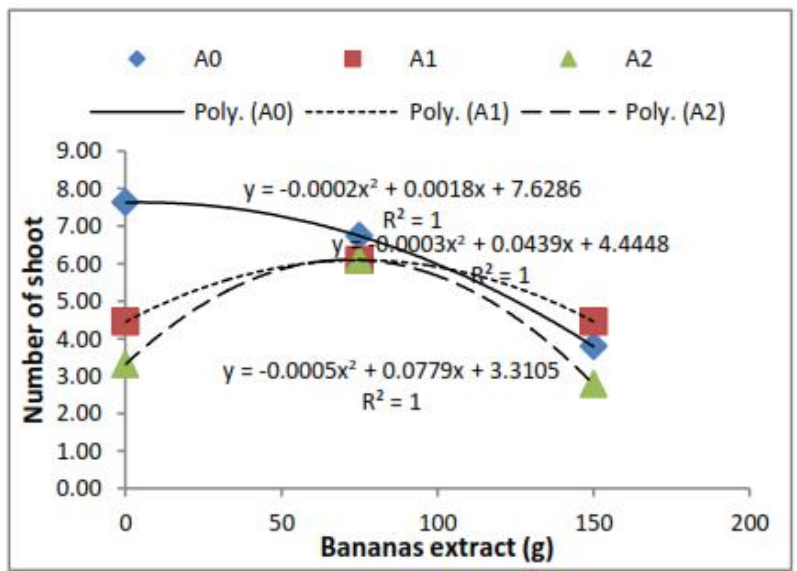

Figure 13. Response of number of shoot on the banana extract at the various levels of coconut water

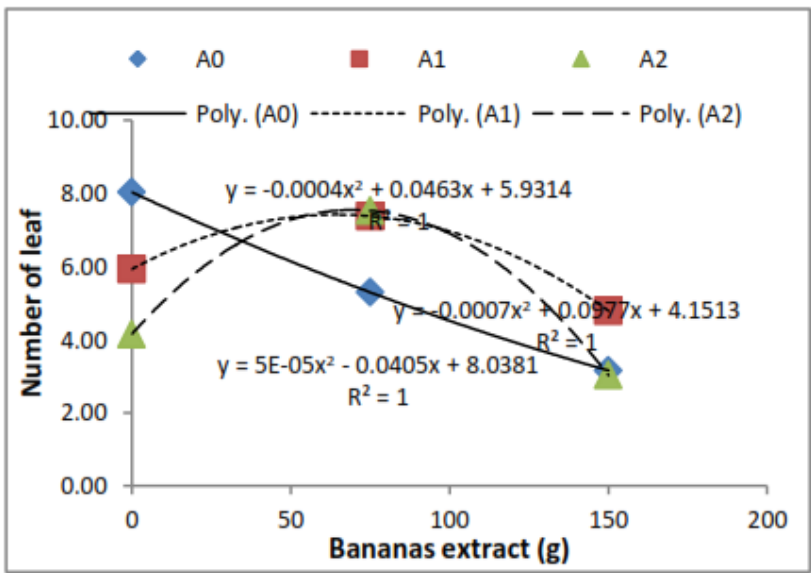

Figure 15. Response of number of leaf on the banana extract at the various levels of coconut water

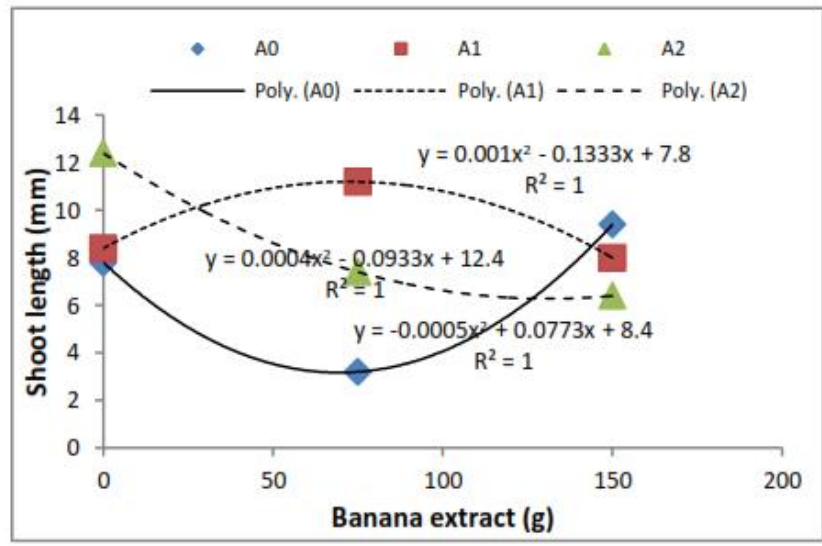

Figure 12. Response of shoot length on the banana extract at the various levels of coconut water

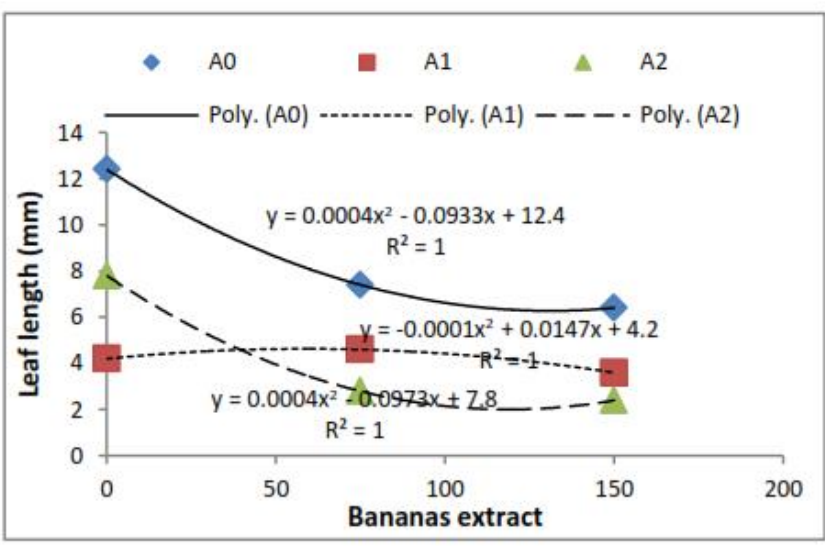

Figure 14. Response of leaf length on the banana extract at the various levels of coconut water

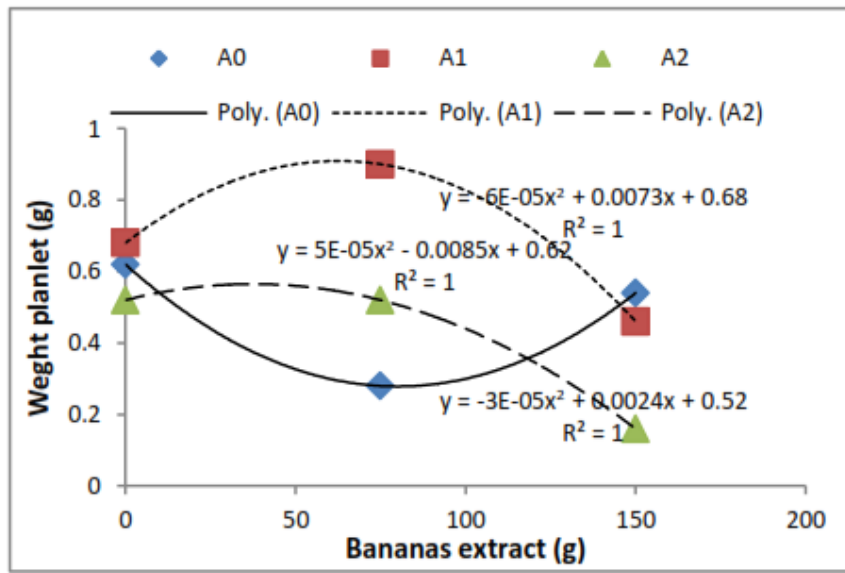

Figure 16. Response of weight plantlet on the banana extract at the various levels of coconut water 
Otherwise, the banana extract treatment gave a good response at a coconut water concentration of $75 \mathrm{ml} . \mathrm{L}^{-1}(\mathrm{~A} 1)$ to the variable shoot length (Figure 12), number of shoots (Figure 13), leaf length (Figure 14), number of leaves (Figure 15), and plantlet weight (Figure 16), where banana extract reaches the optimum between 50-100 g. It was due to the presence of nutrients and growth regulators in coconut water as well as mineral content in bananas, causing interactions to spur plantlet growth, so that the concentration of both treatment was lower than given individually.

According to Suhartanto. et al. [24] that bananas are often used as a source of organic matter in tissue culture media, because 100 grams of banana flesh contain protein $(1 \%)$, fat $(0.3 \%)$, carbohydrates $(27 \%)$, energy (116 -128 kcal), minerals (Ca $15 \mathrm{mg}, \mathrm{K} 380 \mathrm{mg}$, Fe 0.5 $\mathrm{mg}$, Na $1.2 \mathrm{mg}$, and Vitamins (Vit. A $0.3 \mathrm{mg}$, Vit. B1 0.1 $\mathrm{mg}$, B2 $0.1 \mathrm{mg}$, B6 $0.7 \mathrm{mg}$, Vit. C. Addition of BAP 2 mg. $\mathrm{L}^{-1} \mathrm{l}$, coconut water $150 \mathrm{ml} . \mathrm{L}^{-1}$ and $50 \mathrm{~g} . \mathrm{L}^{-1}$ Ambon banana extract had the same effect on increase in the number of shoots, an average of 2 shoots of Phalaenopsis amabilis [21]. The highest number of shoots was produced in media supplemented with $50 \mathrm{ml} . \mathrm{L}^{-1}$ coconut water and 50 g. $\mathrm{L}^{-1}$ potato extract, while media supplemented with $150 \mathrm{ml} . \mathrm{L}^{-1}$ coconut water and 50 potato extracts increased the number of leaves and the number of roots [9].

\section{CONCLUSION}

Coconut water did not affect all observed variables, however the banana extract treatment had a significant effect on all observed variables except for the number of shoots. There was an interaction between the two treatments, where coconut water and banana extract had a good response on the plantlet growth when given together as much as $75 \mathrm{ml} . \mathrm{L}^{-1}(\mathrm{~A} 1)$ and $75 \mathrm{~g} . \mathrm{L}^{-1}(\mathrm{~B} 1)$. The concentration of both treatment was lower than it was given individually based on the results of previous studies.

\section{REFERENCES}

[1] D. Puchooa, 'Comparison of different culture media for the in vitro culture of Dendrobium (Orhidaceae)'. Int. J. Agric. Biol.,vol. 6, pp. 884-888,2004, doi: 15608530/2004/06-5-884-888.

[2] S. K. Talukder, K. M. Nasiruddin, S. Yesmin, R. Begum, and S. Sarker, S. 'In vitro Root formation on orchid plantlets with IBA and NAA'. Progressive Agric. Vol. 13, no.1-2, pp. 25-28, 2002.

[3] A. Suryana, 'Prospects and Directions for Orchid Agribusiness (Prospek dan Arah Pengembangan Agribisnis Anggrek)'.Dev. Agric. Res. and Dev. Agency. Jakarta, 2005.

[4] The Indonesian Statistics Agency, Statistik-tanamanhias-indonesia-2017. Accessed: Oct. 2, 2020.[Online].Available: https://www.bps.go.id/site/publication/2018/10/05/stati stik-tanaman-hias-indonesia-2017.Jun 2019 17:45:28 GMT.

[5] K.B. Andri, W.J.F.A,'Tumbuan, Potential development of orchid flower agribusiness in Batu City, East Java (Potensi pengembangan agribisnis bunga anggrek di kotabatu Jawa Timur)'. Jurnal LPPM Bidang EkoSosBudKom.Vol. 2, no. 1, pp.19-30, 2015.

[6] Indonesian Environmental and Forestry Research and Development Center, 'Plant Propagation Through Tissue Culture (Perbanyakan Tanaman Melalui Kultur Jaringan)'. Makassar. Bogor. Bogor, 2013.

[7] D. Widiastoety, A. Santi, N. Solvia, 'Effect of myoinositol and activated charcoal on growth of dendrobium orchid plantlets in in vitro culture (Pengaruh Myoinositol dan Arang Aktif terhadap Pertumbuhan Planlet Anggrek Dendrobium dalam Kultur In vitro)'. J. Hort. Vol. 22, no. 3, pp. 205209,2012.

[8] W. Pakum, S. Watthana, K. Srimuang, A. Kongbangkerd, 'Influence of medium component on in vitro propagation of Thais Endangered orchid: Bulbophyllum nipondhii Seidenf'. Plant Tissue Cult. \& Biotech., vol. 26, no. 1, pp. 37-46, 2016, doi: https://doi.org/10.3329/ptcb.v26i1.29765

[9] T. Punjansing, M. Nakkuntod, S.Homchan, P. Inthima, A. Kongbangkerd, 'Influence of Organic Supplements on Shoot Multiplication Efficiency of Phaius tankervilleae var. Alba'.Int. J. of Agric. and Biosyst.Eng, vol13, no. 4, pp.105-109, 2019.

[10] S. Rahmah, T. Rahayu, A. Hayati, 'Study Adding Organic Substances on VW Media for Organogenesis the Dendrobium Orchid in Vitro'. $e$ Jurnal Ilmiah SAINS ALAMI (Known Nature), vol. 1, no. 1, pp.93 - 103, 2018.

[11] Djajanegara, 'Utilization of banana and coconut water waste as a medium for tissue culture for the Moon Orchid (Phalaenopsis amabilis) Type 229 (Pemanfaatan limbah buah pisangdan air kelapa sebagai bahan media kultur jaringan anggrek bulan (Phalaenopsisa mabilis) Tipe 229)'. J. Teknologi Lingkungan, vol. 11, no. 3, pp. 373-380, 2010.

[12] M.Humaira, Z. Thomy, E. Harnelly, 'The effect of giving coconut water and banana pulp to MS medium on the growth of rabbit orchid plantlets (Dendrobium antennatum lindl.) In vitro (Pengaruh pemberian air kelapa dan bubur pisang pada media ms terhadap pertumbuhan planlet anggrek kelinci (dendrobium antennatum lindl.) secara in vitro)'.Proc. of Biotic Seminar Nasional, pp. 326330, 2015.

[13] J. Pratama, 'Modification of MS Media with Addition of Coconut Water for Subculture I Cymbidium Orchids (Modifikasi Media MS Dengan Penambahan 
Air Kelapa Untuk Sub kultur I Anggrek Cymbidium)'.Jurnal Agrium, vol. 15, no. 2, pp. 91109, 2018.

[14] N.P.Y.A. Dewi, 'The Effect of Giving Coconut Water on Embryo Development in Dendrobium anosmum Lindl (Pengaruh Pemberian Air Kelapa terhadap Perkembangan Embrio pada Dendrobium anosmum Lindl)'. JBE, vol. 4, no. 1.Pp. 22-28, 2019.

[15] Nurfadilah, E. Mukarlina, P.W. Rusmiyanto, 'The multiplication of black orchids (Coelogyne pandurata Lindl) on murashige skoog (MS) media with the addition of Ambon banana extract and benzyl amino purine (BAP) (Multiplikasi anggrek hitam (Coelogyne pandurata Lindl ) pada media murashige skoog (MS) dengan penambahan ekstrak pisang ambon dan benzyl amino purin (BAP)'. Protobiont,vol. 7, no. 3, pp. 47 -53, 2018.

[16] M. Vargas, B. Glaz, G. Alvarad, J. Pietragalla, A. Morgounov, Y. Zelenskiy, and J. Crossa, 'Analysis and Interpretation of Interactions in Agricultural Research'. Agronomy Journal, vol. 107, no. 2, pp.748, 2015, doi:10.2134/agronj13.0405

[17] M.G. Pranata, A. Yunus , B. Pujiasmanto, 'The effect of NAA concentrations and coconut water on the multiplication of ginger (curcuma xanthorrizha roxb.) In vitro (Pengaruh konsentrasi naa dan air kelapa terhadap multiplikasi temulawak (curcuma xanthorrizha roxb.) secara in vitro)'.Caraka Tani-J. of Sustainable Agric, vol. 30, no. 2, pp.62-68, 2015.

[18] L. Erfa, Ferziana, 'Growth of Phalaenopsis orchid seedling into plantlets in subculture II media with addition of tripton and atonic (Pertumbuhan seedling anggrek Phalaenopsis menjadi plantlet pada media sub kultur II dengan penambahan tripton dana tonik)'. Jurnal Penelitian Pertanian Terapan. Vol. 12. (Spec. Ed.), pp. 52-58,2012.

[19] N.N. Kristina, Syahid, S. Fatimah, 'The Effect of Coconut Water on In Vitro Shoot Multipication, Rhizome Production, and Xanthorrhizol Content of Temulawak in the Field (Pengaruh Air Kelapa Terhadap Multipikasi Tunas In Vitro, Produksi Rimpang, dan Kandungan Xanthorrhizol Temulawak di Lapangan)'. Jurnal Litri, vol. 18, no. 3, pp. 125134, 2012.

[20] J. Yong, L. Ge, Y.F. Ng, S. Tan, 'The chemical composition and biological properties of coconut (Cocos nucifera L.) water'.Molecules, vol. 14, no. 12, pp., 5144-5164, 2009, doi: https://doi.org/10.3390/molecules14125144

[21] Kasutjianingati, R. Irawan, 'Alternative media for in vitro orchid propagation (Phalaenopsi samabilis) (Media alternative perbanyakan in vitro anggrek Bulan (Phalaenopsis amabilis)'. J. Agroteknos, vol. 3, no. 3, pp. 184-189, 2013.

[22] D.P.S. Hendaryono, 'Orchid nursery in bottles (Pembibitan anggrek dalam botol)'. Kanisius: Yogyakarta. 2000

[23] S. Damiska, R.S. Wulandari, H. Darwati, 'Addition of Yeast and Corn Seed Extract to In-Vitro Growth of Mangosteen Shoots (Penambahan Ragi dan Ekstrak Biji Jagung terhadap Pertumbuhan Tunas Manggis Secara In-Vitro)'. J Hutan Lestari, vol. 3, no. 1, pp. 35-42, 2015.

[24] M.R. Suhartanto, Sobir, H. Harti, 'Healthy Technology for Banana Cultivation: From Seed to Post Harvest (Teknologi Sehat Budidaya Pisang: dari Benih sampai Pasca Panen)'. Pusat Kajian Hortikultura Tropika, LPPM-IPB. 2012. 